流機械では最大減速比はボスで生ずるが，本文で述へ る斜流形式では通常外周部で生ずる。ボスでは要求に より増速にも減速にも設計できる。斜流羽根車では軸 流々異なって自由うず形でもねじりが少ないのでこ れを强制うず形としてボス形状を適当に選ぶと水じり なしの羽根車ができ，非常に経済的である。他の夕一 ボ機械と比較を行なうと，この混流形羽根車は同外径 の軸流羽根車よりかなり高い圧力係数を呈しうること がわかる．試験結果によればねじりのない，一定そり の羽根断面を有する羽根車で效率 $94 \%$, 圧力係数 $\psi$ $=2 g H / u_{t}^{2}=1.37$ がえられた。この試験は外径 94〜 $1960 \phi の \Gamma$ 混流形」羽根車を有する送風機について なされたものである。 [大島 政夫]

$532.5: 536 . \overline{25}$

[100]細胞の熱対流理論に対する寄与〔E. PaIm \& H. Plann, J. Fluid Mech., 1964-7, Vol. 19, No. 3，p. 353〜365]，細胞の熱対流問題を扱った最 近の論文では，六角細胞が優先的である理由を述へて いる. 線形化された方程式がこの問題に答えを与えな いのは明らかで，臨界レイノルズ数に達したとき， $K^{2}$ $+l^{2}=r^{2}$ を満足するすべての波は，線形理論にしたが って成長し始める〔ここに $K, l$ は $x, y$ 方向の波 数， $r^{2}$ は境界条件の性質による量]. 本猃文では一般 的見地から考察した。 まず温度とともに粘性の変化が 十分大きい場合，六角細胞に対応する解は二つの波の 成分だけを考えれば，安定な解であること，さらに運 動が任意の波の成分数からなるとき，この結果が真か ぞうか調へるため，三つの波の成分の昜合についても 検討を加えた。この結果の妥当性に対しては容易に波 の成分の一層一般の部類にひろがり, 六角細胞に対応 する解は，生じると思われるあらゆる小さい乱れにつ いて安定なことを示した。これを証明するには非線形 乱れ理論を適用する必要がある。【湯浅 泰伸]

\section{$532.529: 532.542$}

〔101]高圧系からの蒸気 - 水臨界流 [F.R. Zaloudec, $H W-80535,1964$, p. 1 21, 図 7] 短管 $(L /$ $D=20 ） に お け る$ 蒸気・水二相流の臨界放出量を, 上 流僓圧力が 2000 psia までの範囲で調べている.

テスト部の直径は 0.505 in で, 傾科 $20^{\circ}$ の円すい 状入口を持っている. 入口エンタルピは約 425,460 , 485，530 BTU/lb である.

実験の結果は，入口においてすでに蒸気・水混合物 である場合は, 閌そく現象は出口において起り, Fauske の臨界流の理論とよく一致する. しかし, 管の中 あるいは円すい状入口部の中で二相流になる場合は, 閉そく現象は入口で生じ，同じ出口压力に対して䛻界 質量速度はずっと大きい值になる。すなわち

$$
G=C \sqrt{\frac{2 g}{v_{f}}\left(P_{u p}-P_{s a t}\right)}\left(400<P_{u p}<1800 \mathrm{psia}\right)
$$

ここに $G$ : 臨界質量速度, $P_{u t}$ ：上流側圧力, $P_{\text {sat }}$ : 飽和圧力, $v_{f}$ : 飽和水の比体積, $C$ : 縮流係数で 0.95 である。 [安達公道]

$532.529: 536.423$

产[102] エントロピ増加最小原理による汽水二相流の 余気体積率の算定法 [S. M. Zivi, Trans. ASME, Ser. C,1964-5, Vol. 86, No. 2, p. 247〜252, 図 8] 汽水二相流の蒸気体積率の決定に，エントロビ増加最
小原理の適用を試みたものである。すなわち，蒸発を 伴う汽水二相流路に打ける流体の損失エネルギを最小 にするような条件から，蒸気体積率を求めるのであ る. 解析は加速損失の大きな場合を想定していて，損 失エネルギとしては流路から持ち去られる運動エネル ギのみがこれに相当するとした場合と，摩擦損失がこ れに加わった場合とを検討している．前者について はエントレーメントの有無も調へられており,この結 果と後者の結果とを比較して，エントレーメントの大 きさが苲気体積率に重要な因子であると結論してい る.な㧈本解析結果の実際例への適用には，たとえ摩 擦損失エネルギが小さいときでも，エントレーメント の大きさが既知でなければ蒸気体積率は決まらない. さらに，摩擦損失の影響を無視できないときには，あ らためて十分な検討が必要となる。【世古口，言彥]

\subsection{9 : $536.24 / .25$}

〔103]気液二相流の熱伝達 : 第 2 報 環状流路を流

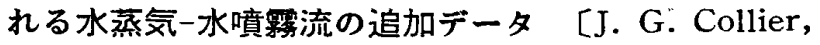
P. M. C. Lacey, \& D. J. Pulling, Trans. Inst. Chem. Engr., 1964, Vol. 42, No. 4, p. 127 139, 図 9, 表 4]本報で報告されているのは外管ガラ ス（内径 0.866 in および 0.551 in), 内管ステンレス 鋼（外恁 0.625 in および 0.375 in）の環状流路（長 さ 48 in おょび 29 in) での箺験で, 加熱は内管の電 気抵抗加熱によっている. 実験範国は, 大口区 15.8〜 $80.3 \mathrm{psi}$ ，汃わき度 $0 \sim 65.9 \%$, 流量 $9.87 \sim 79.4 \times$ $10^{4} \mathrm{lb} / \mathrm{h} \mathrm{ft}$, 熱流束 $3.17 \sim 25.2 \times 10^{4} \mathrm{BTU} / \mathrm{h} \mathrm{ft}{ }^{2}$ で, 流動樣式は噴霧流である。

第 1 報(1)のデータも含めて，対流域に対し標準偏差 $26.9 \%$ で次の実験式を得た。

$$
\begin{aligned}
& \frac{h_{T P}}{h_{L}}=2.167\left(\frac{1}{X_{t t}}\right)^{0.699} \\
& h_{L}=0.023-\frac{k_{L}}{D_{e}}\left[\frac{D_{e} G(1-x)}{\mu_{L}}\right]^{0.8}\left(\frac{C_{P L} \mu_{L}}{k_{L}}\right)^{0.4} \\
& \frac{1}{X_{t t}}=\left(\frac{x}{1-x}\right)^{0.9}\left(\frac{v_{G}}{v_{L}}\right)^{0.5}\left(\frac{\mu_{G}}{\mu_{L}}\right)^{0.1}
\end{aligned}
$$

物性值は $T_{f}=T_{\mathrm{sat}}+0.33 \Delta T_{\mathrm{sat}}$ での值をとる。

Hewitt の対流域の理論式(2) は実験との一致はょく ない，核沸騰域から対流域への遷移点を, nucleation に必要な温度境界㞒厚さ(3)と管内流の液膜厚さが等し くなる点であると仮定して計算したところ実験とよく 一致した。

(1) J. A. R. Bennett, et al., Trans. Inst.Chem. Engr., 39 (1961), 113.

(2) G.F. Hewitt, AERE Peport, R 3680-1 961 ; R 39841962 .

(3) Y. Y. Hsu, ASME Paper, 51-WA-177 (1961).

[中西 重康]

$532.529: 621.039 .536$

※[104] 垂直管内の抵抗体を通過する汽水二相流の圧 力降下 [J.O. Cermak, J. J. Jicha, \& R. G. Lightner, Trans. ASME, Ser. C, 1964-5, Vol. 86, No. 2, p. 227〜239, 図 14, 表 6] 沸騰水形原子炸の炉 心出口に原板オリフィスまたは先細ノズルをそう入す ることがあるが，このような抵抗体を汽水二相流体が 通過する場合の圧力降下を実験的に求めている．実験 はオリフィス 3 種類 (口径: $0.250,0.350,0.425 \mathrm{in}$, 管径 : $0.500 \mathrm{in}$ )，ノズル 2 種類 (口径: $0.250,0.370$ 